\title{
Long-term care financing in Europe: An overview
}

\author{
Anne Neubert ${ }^{1,2,3}$ (D) http://orid.org/0000-0002-6323 \\ Petra Baji ${ }^{4}$ (1) https://orid.org/0000-0003-2899-8557 \\ Marzena Tambor 5 (1) https://orid.org/0000-0001-7970-6919 \\ Wim Groot ${ }^{3}$ (1) htpp://orcid.org/0000-0003-1035-5916 \\ László Gulácsi ${ }^{4}$ (1) https://orcid.org/0000-0002-9285-8746 \\ Milena Pavlova ${ }^{3}$ (1) https://orid.org/0000-0002-6082-8446
}
${ }^{1}$ Department of Orthopaedics and Traumatology, Medical Faculty, Heinrich Heine University Düsseldorf, Düssel- dorf, Germany
${ }^{2}$ Institute for Health Service Research and Health Economics, Centre for Health and Society, Heinrich-Heine-Uni- versity, Düsseldorf, Germany
${ }^{3}$ Department of Health Services Research, CAPHRI, Faculty of Health, Medicine and Life Sciences, Maastricht University, Maastricht, the Netherlands
${ }^{4}$ Department of Health Economics, Corvinus University of Budapest, Budapest, Hungary
${ }^{5}$ Department of Health Economics and Social Security, Institute of Public Health, Faculty of Health Sciences, Jagiel- lonian University Collegium Medicum, Cracow, Poland

Address for correspondence: Anne Neubert, Department of Orthopaedics and Traumatology, Medical Faculty, Heinrich Heine University Düsseldorf, Moorenstrasse 5, 40225 Düsseldorf, Germany, +49 21181 06506, anne.neubert@ med.uni-duesseldorf.de

\section{Abstract}

Despite the growing interest in the sustainability of long-term care (LTC) systems, only a few studies have investigated the differences in the LTC financing across European countries. The objective of this paper is to describe the financing of LTC in Europe. For this purpose, we use indicators on LTC financing taken from international databases and reports. Desk research was carried out to identify relevant indicators. Hierarchical cluster analysis was used to identify typologies in LTC financing across the EU/EEA countries based on seven indicators selected. We found large differences in LTC financing across the EU/EEA countries in terms of total expenditure, the division of expenditure between the social and health care system, and in the role of in-kind and cash benefits. Four main financial models across the EU/EEA countries could be distinguished. Further, we identified some shortages in data reporting on the financing of LTC services. Some limitations and contradictions related to the indicators of LTC financing are highlighted. In particular, we stress the need for more comprehensive data to enable further cross-country comparisons and to provide valid input for policy.

\section{Key words: cluster analysis, Europe, financing, funding, Iong-term care}

\section{Stowa kluczowe: analiza skupień, Europa, finansowanie, opieka dtugoterminowa}

\section{Acknowledgements}

Milena Pavlova is the recipient of an AXA Award of the AXA Research Fund, Project "EuroLTCS Project - Innovative Mechanisms for Sustainable Long-Term Care Systems in Europe". The content of this publication represents the views of the authors and it is their sole responsibility; it can in no way be taken to reflect the views of the AXA Research Fund. 


\section{Introduction}

There is a rising interest in the sustainability and financing of long-term care (LTC) for older citizens in Europe. LTC is defined as "care for people needing support in many facets of living over a prolonged period" [1]. Sustainability of this type of care is challenged due to financial pressure combined with demographic changes, such as population aging, as well as the changes $\mathrm{n}$ of demographic and social structures, like decreasing birth rates, changing family structures, and increasing women's labor participation [2].

A dedicated source of LTC financing such as LTC (public or private) insurance is not a common solution in European countries [3-5]. Furthermore, expenditures on LTC across EU Member States vary considerably. In 2013, the average EU spending on LTC was 1.3\% of GDP but in EU Member States that entered the EU after the year 2004, the expenditure was still significantly lower (EU13 median $=0.7 \%$ of GDP) [6]. It is expected that the expenditure for LTC will increase on average (EU28) by $1.2 \%$ until the year $2060[7,8]$. While countries like the Netherlands allocate about $25 \%$ of the health care system budget to LTC, the Southern and Central-Eastern European (CEE) countries spend much less due to the high share of informal caregiving in the sector [9]. In the OECD counties, the costs of LTC can amount up to $60 \%$ of the disposable household income [10]. Hence, expenditure on LTC represents a substantial financial burden even for those who are financially better off.

In relation to the demographic changes and the rising cost, the financial sustainability of LTC systems are of great interest [11]. Nevertheless, only a few studies have been published in the recent years that compare the LTC financing in the EU/EEA $[3-5,12]$. Hence, we provide a new cross-country analysis on LTC financing across EU/ EEA countries to be compared to previous studies, and to outline directions for new investigations in this area.

The aim of this study is to analyze and compare LTC financing systems across the EU/EEA countries, and to explore their diversity and dynamics. Specifically, we aim to explore data on the level and structure of LTC expenditure in the EU/EEA countries, which gives us insights on how LTC resources are collected and spent. For this, a desk research was conducted to identify indicators related to LTC financing available in international databases and reports. After, using these indicators, we carried out a cluster analysis to reveal existing typologies of LTC financing in the EU/EEA countries. Our work is expected to provide insights in the LTC financial schemes implemented in EU/EEA countries and provide input for policy makers for more informed decision making on LTC financing.

\section{Conceptual framework}

The system of LTC refers to the organization, financing and delivery of a wide range of services, supportive actions and assistances to individuals, who are restricted in their daily ability to function independently over a long- lasting period $[13,14]$. LTC contains services that help these individuals to improve or sustain their quality of life and autonomy.

Since LTC is fundamentally different from health care, typologies or models used to analyze the health care systems have substantial drawbacks when used to analyze LTC systems. In contrast to health care, LTC is embedded both in the health care system and the social care system as it consists of components of medical and non-medical services [14]. The boundaries between these two types of services can be diverse across countries [15]. Hence, we suggest an adaptation of the health care triangle (users/citizens, service providers and payers) [16] by adding LTC within the health care system and the social care system [17]. Additionally, we recognize that contextual factors, such as political, cultural, social, historical, economic and demographic factors, influence the LTC systems. These presumptions are used in this study to assess the financial arrangements in the EU/EEA countries.

Contextual factors that form the LTC system, are the same as for the overall health and social system. The effect of demographic factors on LTC has been extensively shown by other scholars and reports [7, 8, 18, 19]. Nevertheless, the relation between demographic factors and LTC is much more pronounced than in the field of health care as the share of old and very old people in the society is considered to be the key determinant for LTC expenditure [7, 8, 14]. Furthermore, ageing itself has an influence on political and societal factors as well. Some of the factors are influencing LTC in a very specific way, for example, the social belief about the responsibilities for care determines the share of informal and formal care in a country [20]. The amount of expenditure spent by countries is an important determinant of the level of informal care, e.g. informal care is widely used by countries with a low level of LTC spending [21]. Cultural factors in relation with historical factors seem to shape the social protection system in each country in different ways. These determinants influence the demand for different LTC services, as well as the resources needed to provide LTC [22].

Care is often provided in a diversity of settings including home, outpatient and inpatient care by different bodies (family, public, private and voluntary organizations). Furthermore, care services are financed through various resources [15]. Hence, the balance of responsibilities between formal and informal care, as well as public and private (for-profit and non-profit) financing bodies is important $[14,23]$. In general, LTC services can be financed through: (1) out-of-pocket payments, (2) private insurance with risk-premiums (voluntary or mandatory / with or without public support), (3) tax-based system without or with means-testing, and (4) social insurance with income contributions. However, mixed systems are common [24]. Furthermore, especially for public funding, the balance of cash and in-kind benefits is of interest. 


\section{Metholls}

First, desk research was carried out to identify available country-level indicators on LTC financing. The search was conducted in May-June 2017. Then, we carried out cluster analysis using the indicators selected in order to identify financial typologies in the EU/EEA countries.

Indicators on LTC financing were derived from databases of international organizations, namely the WHO, OECD and Eurostat databases. In addition, reports of OECD, WHO, EU were also reviewed for relevant indicators. To assure the consistency of the estimations, an indicator was only used if it contained values for most of the EU/EEA countries. In the few cases of missing indicator values, government websites as well as peerreviewed papers found in PubMed were used to obtain values estimated in a comparable fashion. If comparable data were not available, the values remained missing. When more sources provided values for the same indicator, the data were cross-checked, differences were clarified and one of the sources was used in the study. The indicators identified in the desk research were organized in a data extraction matrix and were classified into four main categories:

1. Total LTC expenditure and the division of health and social expenditure: OECD data were available regarding the total LTC expenditure as a share of GDP, health care expenditure on LTC as a share of GDP, social system expenditure on LTC as a share of GDP [9].

2. LTC Expenditure by financing sources: OECD also reported the share of public expenditure (state or compulsory contributions); and private expenditure (outof-pocket payments, voluntary health insurance contributions and non-profit institutions serving households) in the total LTC expenditure [9].

3. In-kind LTC benefits and cost-sharing: Public spending on in-kind formal care and the share of public spending on institutional and home-care, were derived from EU data sources [6, 7]. Indicators related to costsharing (existence of cost sharing for institutional care, means-testing for cost-sharing in institutional care, existence cost-sharing for home care, means-testing for cost-sharing in home care, evaluating of assets in meantesting, payments by relatives/responsibility of relatives to bear costs of co-payments) were also obtained from [25]. Missing values were replaced as explained above.

4. Cash LTC benefits: Public spending on cash LTC benefits was also derived from EU data sources [6, 7]. Indicators such as the existence of cash benefits, minimum and maximum amount of cash benefits, means-testing for cash benefits, existence of direct payments for informal care were also obtained [25]. Missing values were replaced as explained above. The existence of indirect payments for informal care was also included [26].

Indicators per category were selected and presented in the form of tables to provide an overview of the LTC financing in Europe. Some of the indicators were also used to carry out hierarchical cluster analysis. Indicators included in the cluster analysis presented distinctive aspects of LTC financing. The objective was to identify patterns of LTC financing and thus, to reveal similarities and differences between EU/EEA countries.

Seven indicators were included in the cluster analysis: - Total LTC expenditure as a share of GDP.

- The share of health expenditure in the total LTC expenditure.

- The share of public expenditure in the total LTC expenditure.

- The share of state contribution in the public LTC expenditure.

- The share of out-of-pocket payments in the private LTC expenditure.

- The share of in-kind benefits in the public expenditure.

- The share of institutional care in the public expenditure on in-kind benefits.

These variables were first standardized, and Euclidian distance was used to measure differences between observation points. We used the Ward method for the agglomeration of the cases to ensure homogeneity and relatively equal size of the groups. The analysis was repeated using different methods to check robustness of the classification. Countries were classified to different groups of financial schemes. The optimal number of clusters were determined by the authors based on a dendrogram. Software package SPSS Statistics 24 was used for the analysis.

\section{Results}

Below, we use the selected indicators to outline the LTC financing in EU/EEA countries. The indicators as well as their sources are presented in Table I, II and III.

\section{Total LTC expenditure and the division of health and social expenditure}

According to the OECD data presented in Table I, EU/ EEA countries spend on average $1.47 \%$ of GDP for LTC in total. The Netherlands has the highest expenditure (4.27\% GDP) even in comparison to other high-ranking countries (e.g. Nordic countries). Most CEE countries in the sample (except for the Czech Republic and Slovenia) and Mediterranean countries (except for Malta) spend less than $1 \%$ of their GDP on LTC.

In general, Table I shows that the costs are scattered between the health care system and the social system. The mean spending in the health care system on LTC is $1.20 \%$ GDP and the mean in the social care system is $0.30 \%$ GDP. However, nearly half of the countries in the sample are not able to report costs in the social care system.

The share of health expenditure dedicated to LTC is also shown in Table I. These statistics demonstrate a similar pattern as the total LTC expenditure, i.e. countries with a higher level of LTC expenditure also dedicate a higher share of their health care expenditure to LTC. 


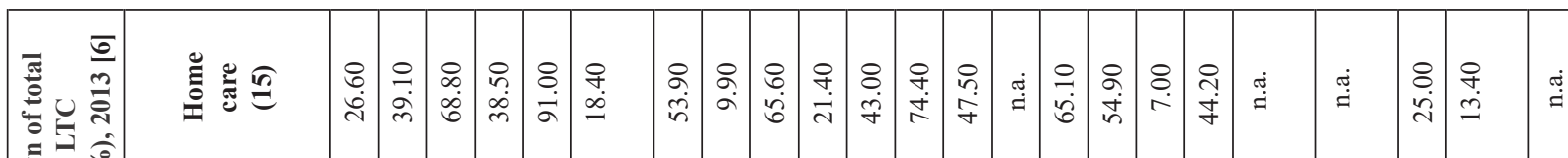

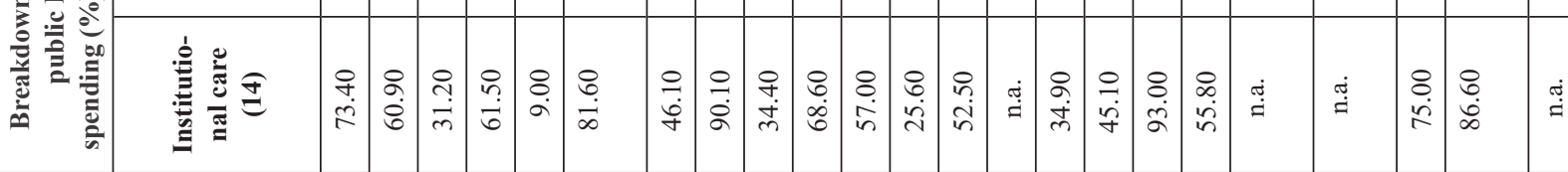

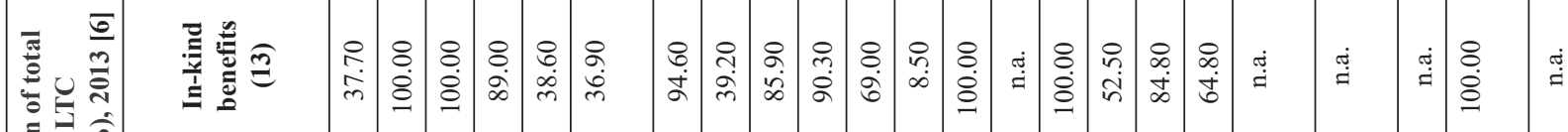

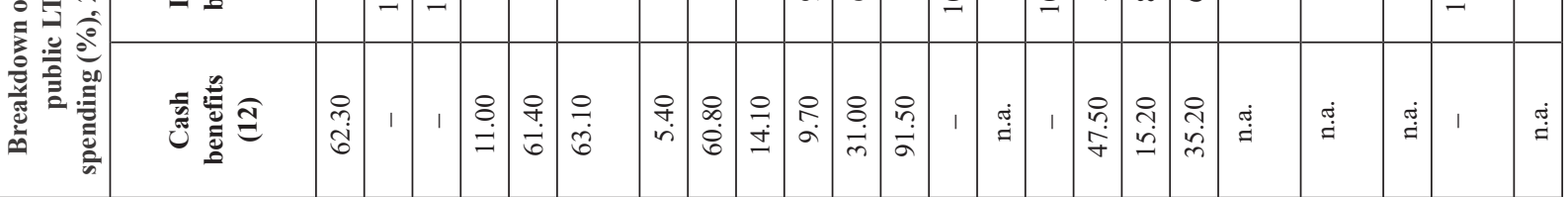

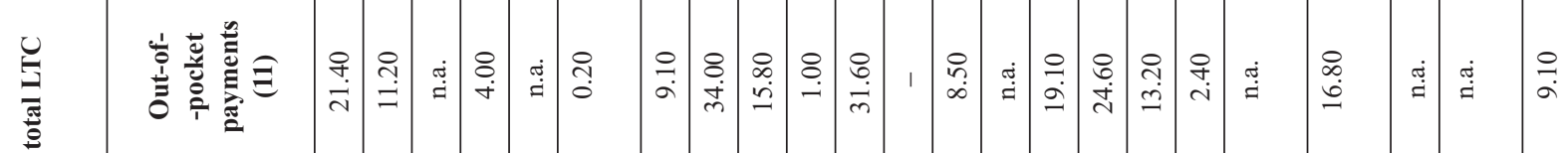

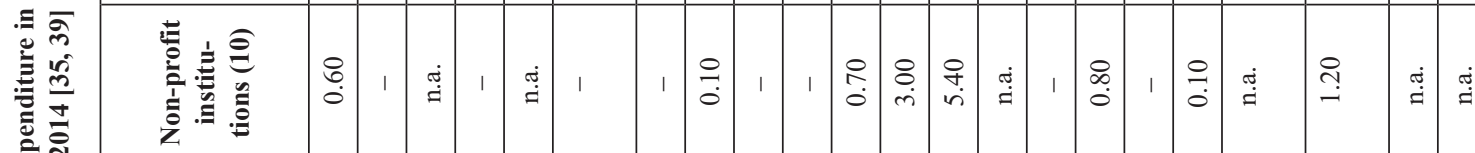

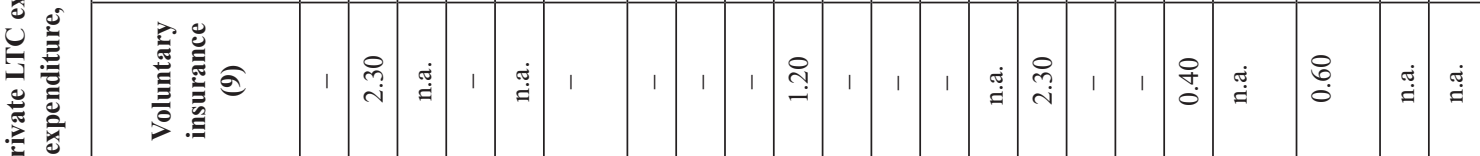

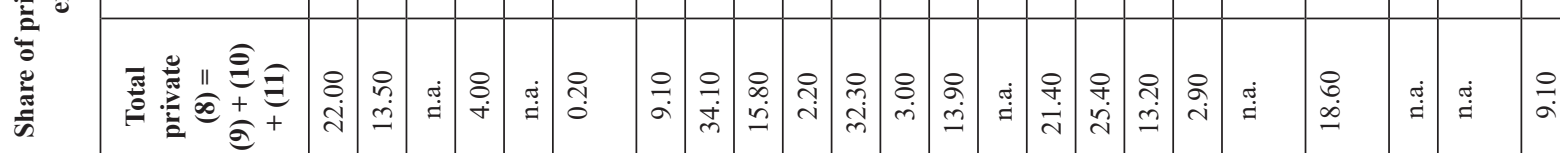

\begin{tabular}{|c|c|c|c|c|c|c|c|c|c|c|c|c|c|c|c|c|c|c|c|c|c|}
\hline \multirow[t]{3}{*}{$\Xi \overline{\bar{d}}$} & 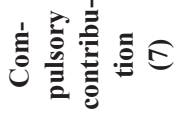 & î̀ & $\begin{array}{l}q \\
\dot{q} \\
\dot{q}\end{array}$ & $\stackrel{\oplus}{\dot{\exists}}$ & & 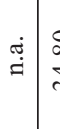 & $\begin{array}{l}0 \\
\infty \\
\dot{m} \\
\dot{m}\end{array}$ & & 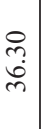 & & \begin{tabular}{l|l}
$\stackrel{9}{+}$ \\
$\dot{\infty}$ \\
$\infty$
\end{tabular} & 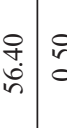 & 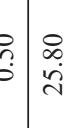 & $\stackrel{?}{\stackrel{P}{6}}$ & $\begin{array}{l}8 \\
: \\
0\end{array}$ & I & $\begin{array}{lll}1 & \tilde{n} \\
\end{array}$ & 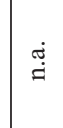 & $\begin{array}{l}9 \\
8\end{array}$ & 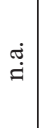 & 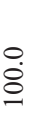 \\
\hline & 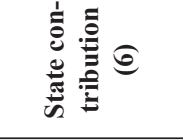 & 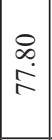 & $\begin{array}{l}\stackrel{?}{\circ} \\
\dot{m}\end{array}$ & $\stackrel{\underset{\nexists}{\sharp}}{=}$ & $\begin{array}{l}8 \\
0 \\
0\end{array}$ & $\underset{\sharp}{\sharp}$ & $\frac{0}{3}$ & $\begin{array}{l}\text { \&े } \\
\text { \&े }\end{array}$ & $\begin{array}{l}9 \\
\text { ते } \\
\text { ते }\end{array}$ & $\begin{array}{l}\text { กิ } \\
\text { +े }\end{array}$ & $\begin{array}{l}q \\
\dot{m} \\
\dot{m}\end{array}$ & 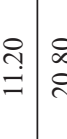 & 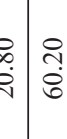 & $\mid \begin{array}{c}8 \\
\infty \\
\infty \\
\infty\end{array}$ & $\mid \begin{array}{l}8 \\
\infty \\
i \\
1\end{array}$ & 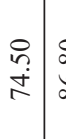 & \begin{tabular}{l|l}
8 \\
$\infty$ \\
$\dot{\infty}$ & \\
$\infty$ & \\
\end{tabular} & $\stackrel{\oplus}{\exists}$ & $\begin{array}{l}\stackrel{9}{+} \\
\text { I }\end{array}$ & 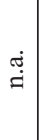 & ' \\
\hline & 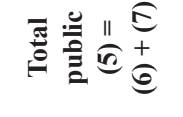 & $\begin{array}{l}\dot{8} \\
\infty \\
i \\
\end{array}$ & 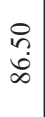 & $\stackrel{\oplus}{=}$ & $\begin{array}{l}8 \\
\dot{0} \\
2\end{array}$ & $\stackrel{\mathscr{J}}{=}$ & 8 & $\begin{array}{l}8 \\
\text { \&े }\end{array}$ & $\begin{array}{l}R \\
\dot{b}\end{array}$ & $\begin{array}{l}\text { บิ } \\
\text { †े }\end{array}$ & 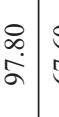 & 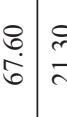 & 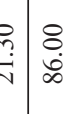 & $\stackrel{\circ}{\dot{\Xi}}$ & $\begin{array}{l}8 \\
\infty \\
\infty \\
1\end{array}$ & $\begin{array}{l}\stackrel{8}{+} \\
\dot{+} \\
+2\end{array}$ & 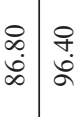 & $\stackrel{\oplus}{=}$ & $\frac{i}{\infty}$ & $\stackrel{\overbrace{}}{\sharp}$ & 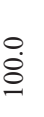 \\
\hline
\end{tabular}

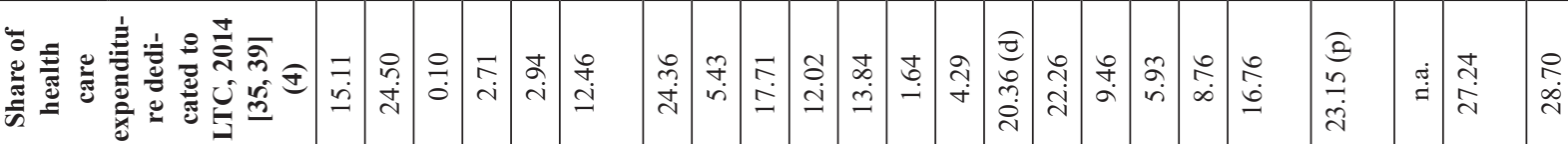

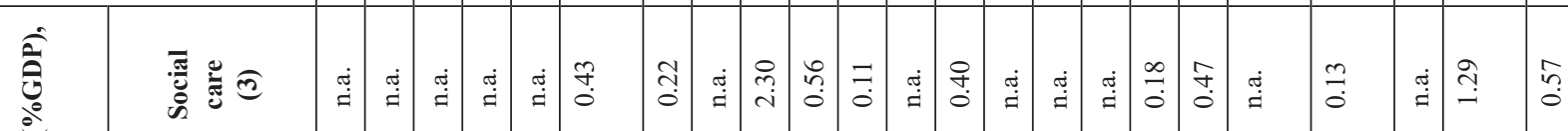

(a)

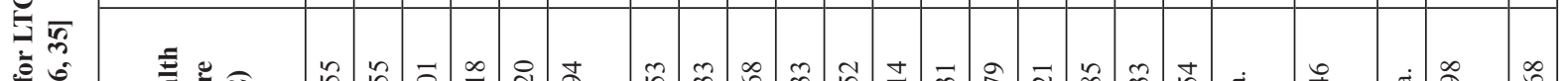

产

童

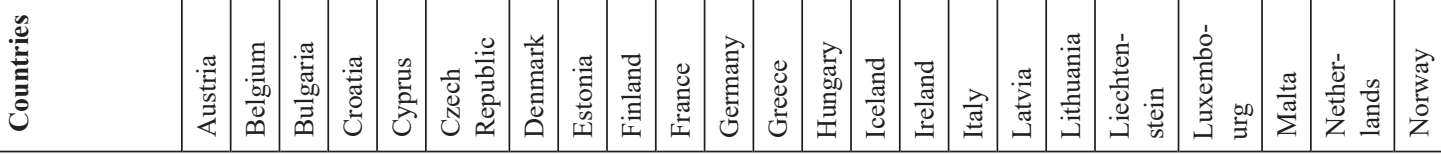




\begin{tabular}{|c|c|c|c|c|c|c|c|c|c|c|}
\hline $\begin{array}{l}\infty \\
\infty \\
\infty \\
\infty\end{array}$ & $\begin{array}{l}\stackrel{0}{1} \\
\infty \\
0\end{array}$ & $\begin{array}{c}\stackrel{1}{1} \\
\infty \\
\infty \\
\infty\end{array}$ & 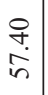 & 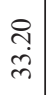 & $\begin{array}{l}\curvearrowright \\
a \\
i \\
\end{array}$ & \begin{tabular}{|l|} 
\\
$\stackrel{9}{a}$ \\
$\dot{q}$
\end{tabular} & 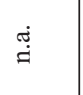 & $\begin{array}{l}\stackrel{8}{ } \\
i \\
i\end{array}$ & $\begin{array}{l}\infty \\
\infty \\
\dot{f}\end{array}$ & $\begin{array}{l}\widetilde{a} \\
\tilde{\sim} \\
\tilde{\lambda}\end{array}$ \\
\hline$\underset{\infty}{\stackrel{\infty}{\infty}}$ & $\begin{array}{l}\infty \\
\dot{m} \\
\dot{m}\end{array}$ & $\begin{array}{l}\infty \\
\doteq \\
=\end{array}$ & $\begin{array}{l}\dot{B} \\
\ddot{f}\end{array}$ & $\begin{array}{l}\infty \\
\infty \\
\dot{0} \\
\dot{0}\end{array}$ & $\begin{array}{l}\stackrel{0}{1} \\
\dot{I}\end{array}$ & $\begin{array}{l}0 \\
\text { m. } \\
\text { in }\end{array}$ & $\stackrel{\overbrace{}]}{=}$ & $\begin{array}{c}\stackrel{q}{+} \\
\stackrel{f}{f}\end{array}$ & $\begin{array}{c}\stackrel{1}{a} \\
\stackrel{n}{n}\end{array}$ & $\begin{array}{l}\tilde{\sigma} \\
\tilde{d} \\
\tilde{i}\end{array}$ \\
\hline $\begin{array}{l}8 \\
8 \\
\dot{0} \\
n\end{array}$ & $\begin{array}{l}\stackrel{\tilde{m}}{2} \\
\stackrel{2}{2}\end{array}$ & $\begin{array}{l}\infty \\
\infty \\
\infty \\
\infty\end{array}$ & $\begin{array}{l}\stackrel{2}{2} \\
\stackrel{n}{2}\end{array}$ & $\begin{array}{l}\stackrel{0}{n} \\
\dot{0}\end{array}$ & $\mid \begin{array}{c}0 \\
i \\
0 \\
0 \\
0\end{array}$ & $\mid \begin{array}{l}q \\
q \\
\dot{0}\end{array}$ & 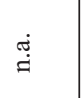 & $\begin{array}{l}R \\
\infty \\
\infty \\
\infty\end{array}$ & $\begin{array}{l}\stackrel{\&}{\stackrel{2}{2}} \\
\stackrel{+}{+}\end{array}$ & $\begin{array}{l}0 \\
0 \\
i \\
\end{array}$ \\
\hline $\begin{array}{l}8 \\
\stackrel{+}{+}\end{array}$ & $\stackrel{0}{\stackrel{0}{0}}$ & $\stackrel{\text { กิ }}{-}$ & $\begin{array}{l}\stackrel{n}{n} \\
\tilde{n}\end{array}$ & 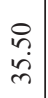 & $\stackrel{?}{\dot{m}}$ & $\begin{array}{l}8 \\
\dot{0} \\
\dot{n}\end{array}$ & $\stackrel{\pi}{=}$ & $\stackrel{\ominus}{=}$ & $\begin{array}{l}8 \\
\dot{i} \\
\text { in }\end{array}$ & $\begin{array}{c}8 \\
\dot{1} \\
i \\
i\end{array}$ \\
\hline 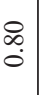 & $\begin{array}{l}\stackrel{R}{R} \\
\infty \\
\infty\end{array}$ & 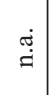 & $\stackrel{\overbrace{}}{-}$ & $\stackrel{?}{i}$ & $\mid \begin{array}{l}\infty \\
\infty \\
2 \\
-\end{array}$ & 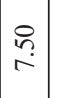 & $\begin{array}{l}\infty \\
\infty \\
\dot{d} \\
\text { i }\end{array}$ & $\begin{array}{l}\stackrel{q}{4} \\
\stackrel{2}{2}\end{array}$ & $\begin{array}{l}\stackrel{\infty}{\stackrel{i}{i}} \\
-\end{array}$ & $\left|\begin{array}{c} \pm \\
\infty \\
0 \\
\varrho\end{array}\right|$ \\
\hline$\underset{\dot{m}}{\stackrel{8}{0}}$ & 1 & 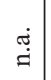 & 1 & $\stackrel{q}{+}$ & $\mid \begin{array}{c}0 \\
n \\
0\end{array}$ & । & $\begin{array}{l}\stackrel{8}{0} \\
i\end{array}$ & $\begin{array}{l}\dot{B} \\
\dot{r}\end{array}$ & $\begin{array}{c}\infty \\
\infty \\
0 \\
0\end{array}$ & 品 \\
\hline 1 & $\stackrel{8}{:}$ & $\stackrel{\oplus}{\dot{g}}$ & 1 & $\stackrel{8}{:}$ & ơ & 1 & $\stackrel{o}{\circ}$ & 1 & $\hat{\overbrace{}}$ & $\mid \begin{array}{l}0 \\
n \\
0\end{array}$ \\
\hline$\underset{+}{\stackrel{q}{+}}$ & 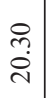 & 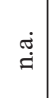 & $\stackrel{\oplus}{-}$ & $\begin{array}{l}\stackrel{P}{r} \\
\dot{m}\end{array}$ & $\begin{array}{l}R \\
\dot{i} \\
\stackrel{2}{2}\end{array}$ & 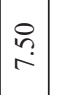 & $\begin{array}{l}\infty \\
\stackrel{\text { ते }}{ }\end{array}$ & $\begin{array}{l}8 \\
\dot{m} \\
\dot{n}\end{array}$ & $\begin{array}{l}\infty \\
m \\
\ddot{n}\end{array}$ & $\exists$ \\
\hline $\begin{array}{l}\stackrel{\text { ले }}{2} \\
\text { ले }\end{array}$ & $\begin{array}{l}\stackrel{\ominus}{7} \\
\dddot{f}\end{array}$ & $\stackrel{\oplus}{=}$ & $\stackrel{\text { ते }}{ }$ & $\begin{array}{l}\circ \\
\stackrel{2}{r}\end{array}$ & $\stackrel{9}{\Xi}$ & I & $\begin{array}{l}8 \\
\stackrel{6}{+}\end{array}$ & 1 & $\begin{array}{l}\vec{\infty} \\
\dot{0} \\
\dot{n}\end{array}$ & $\frac{\text { ț }}{m}$ \\
\hline $\begin{array}{l}8 \\
\stackrel{8}{0} \\
\text { in }\end{array}$ & $\begin{array}{l}\stackrel{q}{+} \\
\dot{+} \\
\dot{m}\end{array}$ & $\stackrel{\leftrightarrow}{\dot{g}}$ & 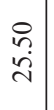 & 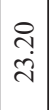 & $\begin{array}{l}0 \\
\tilde{6} \\
\end{array}$ & $\begin{array}{l}0 \\
\stackrel{n}{a} \\
\alpha \\
\sigma\end{array}$ & $\begin{array}{l}\stackrel{ர}{+} \\
\stackrel{N}{N}\end{array}$ & $\begin{array}{l}8 \\
i \\
6\end{array}$ & $\begin{array}{l}\approx \\
\hat{i} \\
\curvearrowleft\end{array}$ & 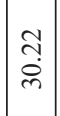 \\
\hline $\begin{array}{l}\stackrel{n}{n} \\
\ddot{n} \\
\alpha\end{array}$ & $\begin{array}{l}\stackrel{2}{2} \\
2\end{array}$ & $\stackrel{\leftrightarrow}{\stackrel{\oplus}{g}}$ & $\begin{array}{l}\stackrel{R}{2} \\
\infty \\
\infty\end{array}$ & 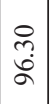 & 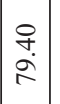 & 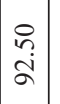 & ஓి & 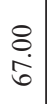 & $\begin{array}{l}\hat{N} \\
\dot{\infty}\end{array}$ & $\left|\begin{array}{l}\infty \\
n \\
0 \\
0\end{array}\right|$ \\
\hline 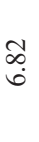 & 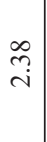 & $\stackrel{\vec{\infty}}{-}$ & $\stackrel{+}{?}$ & 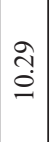 & $\begin{array}{l}\infty \\
\vec{a}\end{array}$ & 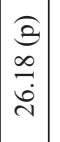 & $\begin{array}{l}\stackrel{\sim}{\sim} \\
\stackrel{2}{2}\end{array}$ & $\hat{a}$ & 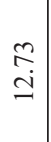 & $\left|\begin{array}{l}\hat{a} \\
\infty\end{array}\right|$ \\
\hline 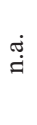 & $\vec{\sigma}$ & $\begin{array}{l} \pm \\
0 \\
0\end{array}$ & $\stackrel{\dot{J}}{=}$ & $\stackrel{?}{\stackrel{p}{0}}$ & $\begin{array}{l}0 \\
0 \\
0\end{array}$ & $\begin{array}{l}n \\
0 \\
0\end{array}$ & $\stackrel{0}{0}$ & $\stackrel{\overbrace{}}{\stackrel{\Xi}{\sharp}}$ & $\begin{array}{c}0 \\
\text { ñ } \\
0\end{array}$ & $\stackrel{\infty}{+\infty}$ \\
\hline$\stackrel{?}{f}$ & $\tilde{\widetilde{o}}$ & $\stackrel{\text { oे }}{\circ}$ & 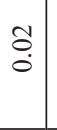 & $\begin{array}{l}\infty \\
\infty \\
0 \\
0\end{array}$ & $\mid \begin{array}{l}\tilde{\infty} \\
\infty \\
0\end{array}$ & $\overrightarrow{\widehat{a}}$ & $\stackrel{\overbrace{}}{N}$ & $\stackrel{尺}{=}$ & $\stackrel{\text { Iิ }}{-}$ & ڤे. \\
\hline$\stackrel{f}{0}$ & $\grave{o}$ & $\stackrel{m}{0}$ & $\stackrel{\leftrightarrow}{0}$ & $\vec{m}$ & 尺. & $\begin{array}{l}\infty \\
\dot{+} \\
\dot{m}\end{array}$ & $\stackrel{\circ}{\stackrel{i}{i}}$ & $\stackrel{ }{-}$ & 守 & $\stackrel{?}{\rightrightarrows}$ \\
\hline$\frac{\pi}{0}$ & $\begin{array}{l}\overrightarrow{I_{0}} \\
\stackrel{0}{0} \\
\overrightarrow{0} \\
0\end{array}$ & 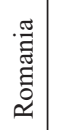 & $\begin{array}{l}\frac{\pi}{d} \\
\frac{\pi}{\pi} \\
\frac{0}{n}\end{array}$ & $\begin{array}{l}\frac{\pi}{\tilde{J}} \\
\frac{\partial}{\omega} \\
\frac{0}{\omega}\end{array}$ & 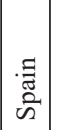 & 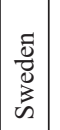 & 离 & 光 & 胥 & 命 \\
\hline
\end{tabular}

\section{Indicators by financing sources}

According to the OECD data in Table I, LTC is largely financed by public sources. On average, $83.77 \%$ (SD $16.58 \%$ ) is financed through public spending. In Iceland, LTC seems to be purely financed by public expenditures and with no private contribution. In the Netherlands, $100 \%$ of the costs for home nursing are apparently financed by compulsory health insurance premiums. Although, in the case of the Netherlands, literature suggests that around $8 \%$ of the total expenditure for LTC is financed through co-payments by LTC users (private expenditure) in 2012 . However, due to legislative changes in the Netherlands in the last years, it is difficult to form a defined statement as no recent literature referred to co-payments. In countries like Germany, United Kingdom, Estonia and Greece, financial expenditure from public sources are significantly below the average for all EU/EEA countries. In all countries but Greece, this can be contributed to an above average share of private expenditure.

In countries, where a high volume of LTC is financed by health insurance (e.g. Switzerland) or LTC insurance (Germany), the share of compulsory contributions is well above the average. The Nordic countries have the highest share of state contributions as their LTC systems are financed by taxes. However, it should be kept in mind that compulsory contribution can also stem from other social security sources, e.g. pension or disability funds depending on the country.

According to the data in Table I, there are several forms of private financing, and the total private LTC expenditure can be as much as $34.10 \%$ in Estonia, with the mean of $13.38 \%$. In general, out-of-pocket payments are the most important private source of LTC financing as their share is on average $12.18 \%$ (SD $10.84 \%$ ), but can be as high as 34\% like in Estonia. However, their actual role is difficult to determine due to significant underreporting. Additionally, the data shown here do only capture private expenditure that are related to formal care. Thus, private expenditure may be significantly higher in some countries than shown in Table I.

On average, voluntary LTC insurance only amounts to about $0.27 \%$ of the total expenditure as such insurance is of limited importance in a few countries (e.g. France, Portugal, Switzerland), as indicated in Table I. Additionally, due to the voluntary LTC insurance schemes, some share of the funding structure is due to cost-sharing arrangements within these insurances.

Furthermore, many countries in the sample finance their LTC systems with sources from non-profit institutions that serve households (abbreviation: NPISH). As indicated in Table I, their mean share is only $0.83 \%$ but can be as high as $5.4 \%$ (Hungary) or play no role at all like in Nordic countries. Moreover, not shown in the Table I, in Ireland, Lithuania and Germany, a limited amount of total expenditure comes from schemes managed by companies that are mostly based on employment. 


\section{Cash benefits}

Countries like Austria, Cyprus, Czech Republic, Greece and Estonia spend more on cash benefits than other countries in the EU/EEA region. Table II presents an overview of cash benefits for care receivers and caregivers. Generally, cash benefits for care receivers are designed to either compensate for formal or informal care (so-called carer blind system), whereas cash benefits for caregivers are a compensation for the informal care provided. Twenty-eight countries in the sample $(87.5 \%)$ offer cash benefits to those in need of care, the rest is offering care only in the form of in-kind benefits or only to caregivers (e.g. Hungary). A special case is Latvia, where generally no cash benefits exist but some municipalities are still granting these benefits.

The amount one can receive as a cash benefit varies highly among the countries. Often countries structure the amount of cash benefits in relation to the level of dependency, therefore, Table II illustrates the minimum and maximum amount of cash benefits one can receive in the given countries. Denmark is granting the highest benefits within the sample, whereas Romania is one of the countries with the lowest amount. The Netherlands is a special case, as the extent of cash benefits is in close relation to the rates formal care providers receive, and users of LTC can choose between in kind benefits or cash benefits with which they can buy their own care. The country spends about $6.5 \%$ of its total LTC expenditure on cash benefits called a Personalized budget. Furthermore, even though Sweden declares to have cash benefits, there is according to the findings only one nationwide cash benefit, a housing supplement (up to $€ 530 /$ month). Depending on the Swedish municipality in charge, an attendance allowance is available for the caregivers. Italy is an example of extensive reliance on cash benefits in combination with a low level of public service provision.

Only about a third of the sample $(n=11)$ is applying means-testing on cash benefits. Thus, for the rest of the sample, cash benefits are universal. However, several exemptions exist. Cyprus is only granting cash benefits to those with a guaranteed minimum income, Croatia is exempting those who have specific illnesses from means-testing, Poland is using means-testing for one of the available allowances and Spain does not apply means-testing when the person is severely incapacitated. Switzerland and Liechtenstein do not use means-testing for cash benefits, but apply it for the reimbursement of LTC or special other expenses. Additionally, Bulgaria, Slovakia and Spain apply means-testing not only on income, but also on assets.

Informal caregivers can receive indirect and direct payments (also called carers' allowances) as a support. Direct payments are cash benefits that are transferred directly to the caregiver, whereas indirect payments are social security contributions (pension, health care etc.) provided by the state. Hence, the latter does not offer cash as a remuneration for the care provided but does nevertheless support caregivers by topping up their social security contribution as informal caregivers are often forced to work part-time or need to stop working at all. As a large extent of care in LTC is provided by informal caregivers, policies for that manner are important for the viability and sustainability of the system as well as to reduce the negative financial and health impacts of informal caregiving. Half of the sample $(n=16)$ is granting caregivers direct cash benefits, even countries in which care receivers do not receive any cash benefits like Hungary, Iceland and Malta. Fifteen countries (46.9\%) offer indirect payments. Furthermore, countries may provide counselling, training and respite care to support informal caregiving, which is not illustrated in Table II.

\section{In-kind benefits}

In-kind benefits amount for the highest share of public expenditure in LTC in most of the countries. As indicated in Table I, most countries in our study invest on average about half of the LTC budget on institutionalized care. However, there are considerable variations with regards to institutional spending in the EU/EEA area. Cyprus is only spending $9 \%$ of the LTC budget on institutional care, whereas Latvia and Estonia are investing nearly the entire budget on it. Vice versa similar observations can be made for home-based care. Only a few countries have nearly evenly divided (50/50) expenditures for home and institutional care, such as Denmark, Germany and Lithuania. In most other countries, a clear focus on either home care or institutional care is visible.

As established, cost-sharing for in-kind services is an important source of financing LTC in many countries in our study (Table III). Thirty countries apply cost-sharing to institutional care but only twenty-three determine the amount of cost-sharing in relation to the user's income. In twenty-five countries, cost-sharing also applies to home-based care. However, only about half of the sample $(n=17)$ uses means-testing to determine the amount of cost-sharing. Belgium and Cyprus are somewhat peculiar cases, as they state no cost-sharing for institutional care, but determine the co-payments with means-testing, even though, Belgium is using flat-rate cost-sharing.

Moreover, eleven countries also use assets (mostly real estate) to cover the costs of LTC services, especially for high cost care such as nursing homes. Relatives of those in need of care must bear the responsibilities in relation to costs arising from LTC in eighteen countries. This is mainly the case in CEE countries within the sample but also two Mediterranean countries (Italy and Spain). Hence, cost-sharing, assets and contributions by relatives are particularly important to cover the costs of institutional care.

\section{Cluster analysis}

As described in the Methods section, 7 indicators were used in the cluster analysis. Due to missing values for some variables, Bulgaria, Cyprus, Iceland, Liechtenstein, Luxembourg, Malta, Norway, Romania, Switzerland could not be included in the analysis. Thus, out of the 33 EU/EEA countries only 23 countries could be classified. 


\begin{tabular}{|c|c|c|c|c|c|c|}
\hline & \multicolumn{4}{|c|}{ Care receiver } & \multicolumn{2}{|c|}{ Caregiver } \\
\hline & $\begin{array}{c}\text { Existence of } \\
\text { cash-benefits } \\
\text { for the LTC } \\
\text { recipient or } \\
\text { to hire assistance } \\
{[25,40]}\end{array}$ & $\begin{array}{l}\text { Min. amount of } \\
\text { cash benefits, } \\
€ / \text { month }[25,41]\end{array}$ & $\begin{array}{l}\text { Max. amount of } \\
\text { cash benefits } \\
€ / \text { month [25] }\end{array}$ & $\begin{array}{c}\text { Means-testing of } \\
\text { cash benefits } \\
{[7,25,42,43]}\end{array}$ & $\begin{array}{c}\text { Direct payments } \\
{[6,40,44]}\end{array}$ & $\begin{array}{c}\text { Indirect pay- } \\
\text { ments } \\
{[25,26]}\end{array}$ \\
\hline Austria & yes & 157.30 & $1,688.90$ & no & no & yes \\
\hline Belgium & yes & 97.65 & 878.66 & yes & no & no \\
\hline Bulgaria & yes & 42.00 & 42.00 & yes & yes & no \\
\hline Croatia & yes & 66.00 & 166.00 & yes & yes & yes \\
\hline Cyprus & yes & not available & not available & yes & no & no \\
\hline Czech Republic & yes & 30.00 & 443.00 & no & no & yes \\
\hline Denmark & yes & $2,002.00$ & $3,936.00$ & no & yes & yes \\
\hline Estonia & yes & not available & not available & yes & yes & yes \\
\hline Finland & yes & 62.25 & 327.67 & no & yes & yes \\
\hline France & yes & 552.08 & $1,656.26$ & no & no & no \\
\hline Germany & yes & 125.00 & 901.00 & no & no & yes \\
\hline Greece & yes & 313.00 & 771.00 & no & no & no \\
\hline Hungary & no & not applicable & not applicable & not applicable & yes & no \\
\hline Iceland & no & not applicable & not applicable & not applicable & yes & no \\
\hline Ireland & yes & not available & not available & no & yes & yes \\
\hline Italy & yes & 206.59 & 899.38 & no & no & yes \\
\hline Latvia & no & not applicable & not applicable & not applicable & no & no \\
\hline Lithuania & yes & 56.00 & 280.00 & no & no & yes \\
\hline Liechtenstein & yes & 428.00 & 855.00 & no & no & no \\
\hline Luxembourg & yes & 25.00 & 262.50 & no & no & yes \\
\hline Malta & no & not applicable & not applicable & not applicable & yes & yes \\
\hline Netherlands & yes & not available & not available & no & yes & no \\
\hline Norway & yes & 72.08 & 259.50 & no & yes & no \\
\hline Poland & yes & 35.00 & 136.00 & yes & yes & yes \\
\hline Portugal & yes & 101.7 & 182.11 & yes & no & no \\
\hline Romania & yes & 9.00 & 52.00 & yes & no & not available \\
\hline Slovakia & yes & not available & not available & yes & yes & yes \\
\hline Slovenia & yes & 146.06 & 418.88 & no & yes & yes \\
\hline Spain & yes & 153.00 & 833.96 & yes & no & no \\
\hline Sweden & yes & not available & not available & yes & yes & no \\
\hline Switzerland & yes & 470.00 & $1,732.00$ & no & no & no \\
\hline $\begin{array}{l}\text { United King- } \\
\text { dom }\end{array}$ & yes & 268.00 & 400.00 & no & yes & no \\
\hline Mean & & 246.23 & 782.81 & & & \\
\hline SD & & 420.96 & 873.39 & & & \\
\hline Frequency Yes & $N=28(87.5 \%)$ & & & $N=11(39.2 \%)$ & $N=16(50 \%)$ & $N=15(48.3 \%)$ \\
\hline Frequency No & $N=4(12.5 \%)$ & & & $N=17(60.8 \%)$ & $N=16(50 \%)$ & $N=16(51.7 \%)$ \\
\hline
\end{tabular}

Note: Frequencies are calculated excluding missing data.

Table II. Cash benefits for care receiver and caregiver.

Source: Own study.

The dendrogram of the cluster analysis is presented in Figure 1 and shows that four groups of countries can be distinguished, while Greece represent a separate case.
The four groups are the following:

Group 1: High expenditure from state contributions and out-of-pocket payments offering mostly in-kind ben- 


\begin{tabular}{|c|c|c|c|c|c|c|}
\hline & \multicolumn{4}{|c|}{ Cost-sharing for in-kind benefits \# } & \multirow{2}{*}{$\begin{array}{c}\text { Assets } \\
\text { Use of assets to } \\
\text { pay for institu- } \\
\text { tional care } \\
{[6,9,25,42,43} \\
45,47-51] \\
\end{array}$} & \multirow{2}{*}{$\begin{array}{c}\text { Role of relatives } \\
\begin{array}{c}\text { Means-testing } \\
\text { of income of } \\
\text { relatives }\end{array} \\
{[6,7,9,25,32,43,} \\
45,46,51-58]\end{array}$} \\
\hline & $\begin{array}{c}\text { Cost-sharing } \\
\text { institutional care } \\
{[9,25,45]}\end{array}$ & $\begin{array}{c}\text { Cost-sharing } \\
\text { income-related - } \\
\text { institution } \\
{[6,7,25,42,45,46]}\end{array}$ & $\begin{array}{c}\text { Cost-sharing } \\
\text { home care } \\
{[6,7,25,45]}\end{array}$ & $\begin{array}{c}\text { Cost-sharing } \\
\text { income-related - } \\
\text { home care } \\
{[6,7,25,42,46]}\end{array}$ & & \\
\hline Austria & yes & yes & Yes & yes & yes & No \\
\hline Belgium & no & yes & yes & yes & no & yes \\
\hline Bulgaria & yes & yes & yes & no & no & yes \\
\hline Croatia (a) & yes & yes & yes & yes & yes & yes \\
\hline Cyprus & no & yes & no & yes & yes & no \\
\hline Czech Republic & yes & no & yes & no & no & yes \\
\hline Denmark & yes & no & no & no & no & no \\
\hline Estonia & yes & yes & yes & yes & yes & yes \\
\hline Finland & yes & yes & yes & yes & no & no \\
\hline France & yes & yes & yes & yes & no & no \\
\hline Germany & yes & no & yes & no & no & no \\
\hline Greece & yes & yes & no & no & not available & yes \\
\hline Hungary & yes & yes & yes & yes & yes & yes \\
\hline Iceland & yes & no & no & no & no & no \\
\hline Ireland & yes & yes & no & no & yes & no \\
\hline Italy & yes & yes & yes & yes & yes & yes \\
\hline Latvia & yes & yes & no & no & no & yes \\
\hline Lithuania & yes & yes & yes & yes & yes & yes \\
\hline Liechtenstein & yes & not available & yes & not available & no & no \\
\hline Luxembourg & yes & no & yes & no & no & no \\
\hline Malta & yes & yes & yes & yes & no & no \\
\hline Netherlands & yes & yes & yes & yes & no & yes \\
\hline Norway & yes & yes & no & no & no & no \\
\hline Poland & yes & yes & yes & no & no & yes \\
\hline Portugal & yes & yes & yes & yes & no & yes \\
\hline Romania & yes & yes & yes & yes & no & yes \\
\hline Slovakia & yes & yes & yes & yes & no & yes \\
\hline Slovenia & yes & no & yes & no & yes & yes \\
\hline Spain & yes & yes & yes & yes & yes & yes \\
\hline Sweden & yes & no & yes & no & no & no \\
\hline Switzerland & yes & no & yes & no & no & yes \\
\hline United Kingdom & yes & yes & yes & yes & yes & no \\
\hline Frequency Yes & $N=30(93.8 \%)$ & $N=23(74.9 \%)$ & $N=25(78.1 \%)$ & $N=17(54.8 \%)$ & $N=11(35.5 \%)$ & $N=18(56.2 \%)$ \\
\hline Frequency No & $N=2(6.2 \%)$ & $N=8(25.1 \%)$ & $N=7(21.9 \%)$ & $N=14(45.2 \%)$ & $N=20(64.5 \%)$ & $N=14(43.8 \%)$ \\
\hline
\end{tabular}

Note: Frequencies are calculated excluding missing data.

Table III. In-kind benefits for care receiver and caregiver.

Source: Own study.

efits with an important role of home care: Countries in Group 1 include Denmark, Sweden, Ireland, UK and Finland. These countries spend a high share of their GDP on LTC ( $2.8 \%$ on average). In these countries, more than $80 \%$ of the expenditure is covered by public resources from state contribution. The private financing is derived from out-of-pocket payments. Almost all resources are dedicated to in-kind benefits with more than half of the expenditure devoted to home-care.

Group 2: Insurance model - a diverse level of expenditure from compulsory contributions, voluntary insurance: Group 2 consists of Belgium, Germany, France, Slovenia, Poland, Slovakia and the Netherlands. Total LTC expenditure as a share of their GDP is medium 


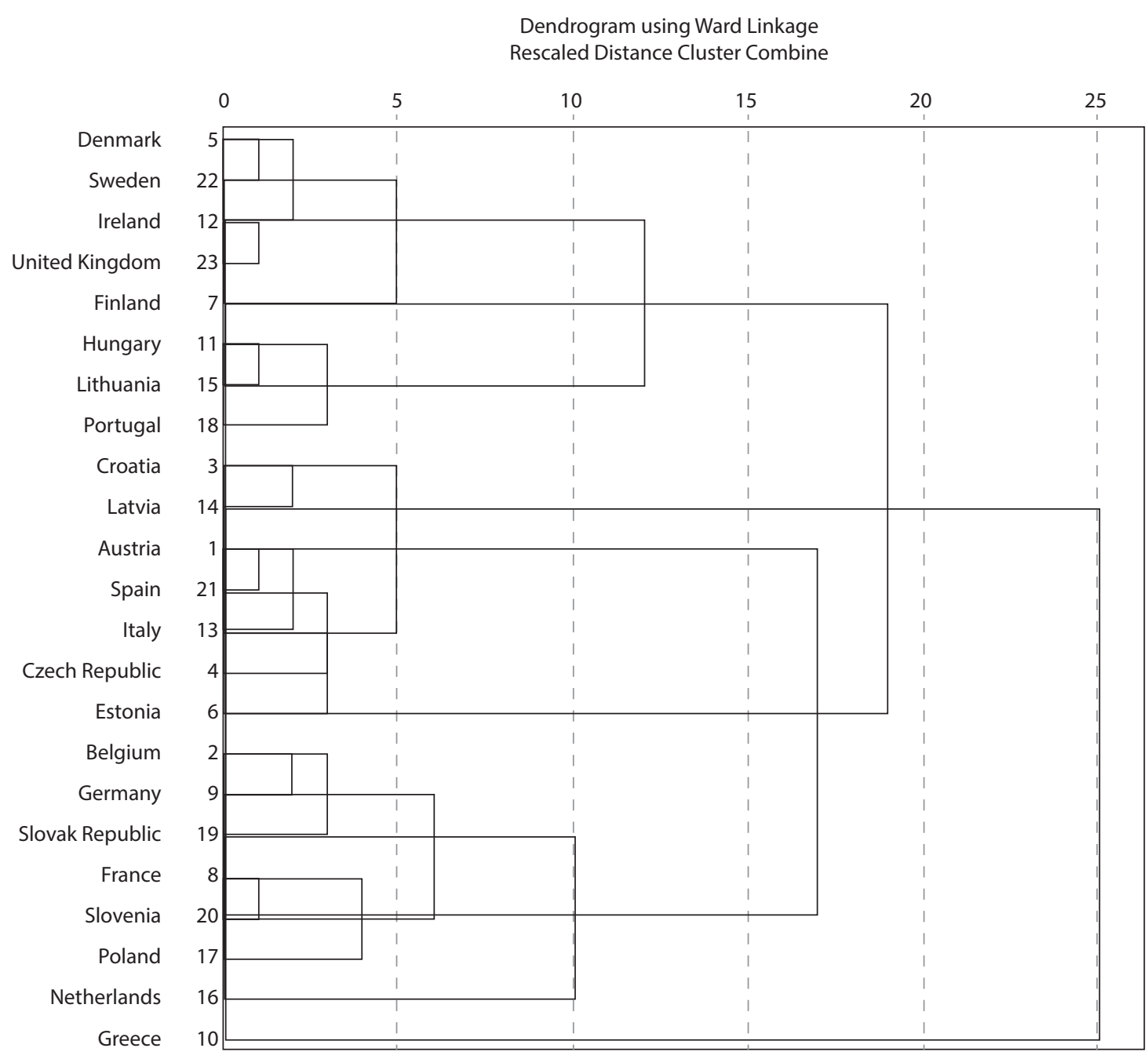

Figure 1. Dendrogram with the cluster analysis results.

Source: Own study.

( $1.7 \%$ on average). Almost all expenditure is covered by public resources, mainly from compulsory contributions. In this group, we can observe a relatively low share of out-of-pocket payments in private financing, which is due to the role of voluntary health insurance or non-profit organizations in financing LTC services. The share of cashbenefits is relatively high, about $30 \%$, while expenditure is devoted mostly for institutional care, more than $60 \%$.

Group 3: Low expenditure from state contributions and out-of-pocket payments, with an important role of cash benefits: The third group includes Austria, Spain, Croatia, Italy, Czech Republic, Latvia and Estonia. Their total LTC expenditure as share of GDP is low $(0.8 \%$ on average) with the highest share of expenditure coming from the health care budget. The share of public expenditure in total expenditure is relatively low compared to other groups (about $80 \%$ ). The source of public expenditure is mainly state contribution. Private expenditure is mostly financed through out-of-pocket payments. The share of cash-benefits is relatively high in this group (above 40\%). Expenditure is mostly devoted to institutional care (approaching 75\%).
Group 4: Low expenditure, mostly from public resources offering mostly in-kind benefits: Being the smallest group, Group 4 includes Hungary, Lithuania and Portugal. In these countries, the share of GDP spent on LTC, is relatively low $(0.9 \%$ on average $)$ and the share of health care expenditure in the total LTC spending is the lowest (40\%). The share of public resources in total expenditure is relatively high (approaching 90\%) coming from the mix of state and compulsory contributions. The share of out-of-pocket payments in private financing is relatively low due to expenditure of nonprofit institutions serving households. Resources are mostly devoted to in-kind benefits and a notably high share of the expenditure is devoted to home-care, more than $40 \%$.

Descriptive statistics of the four groups are shown in Table IV. Greece is not presented here as it constitutes a separate group. According to one-way ANOVA analysis, group-means are significantly different for all variables included in the analysis, except for the share of public expenditure in total LTC expenditure. 

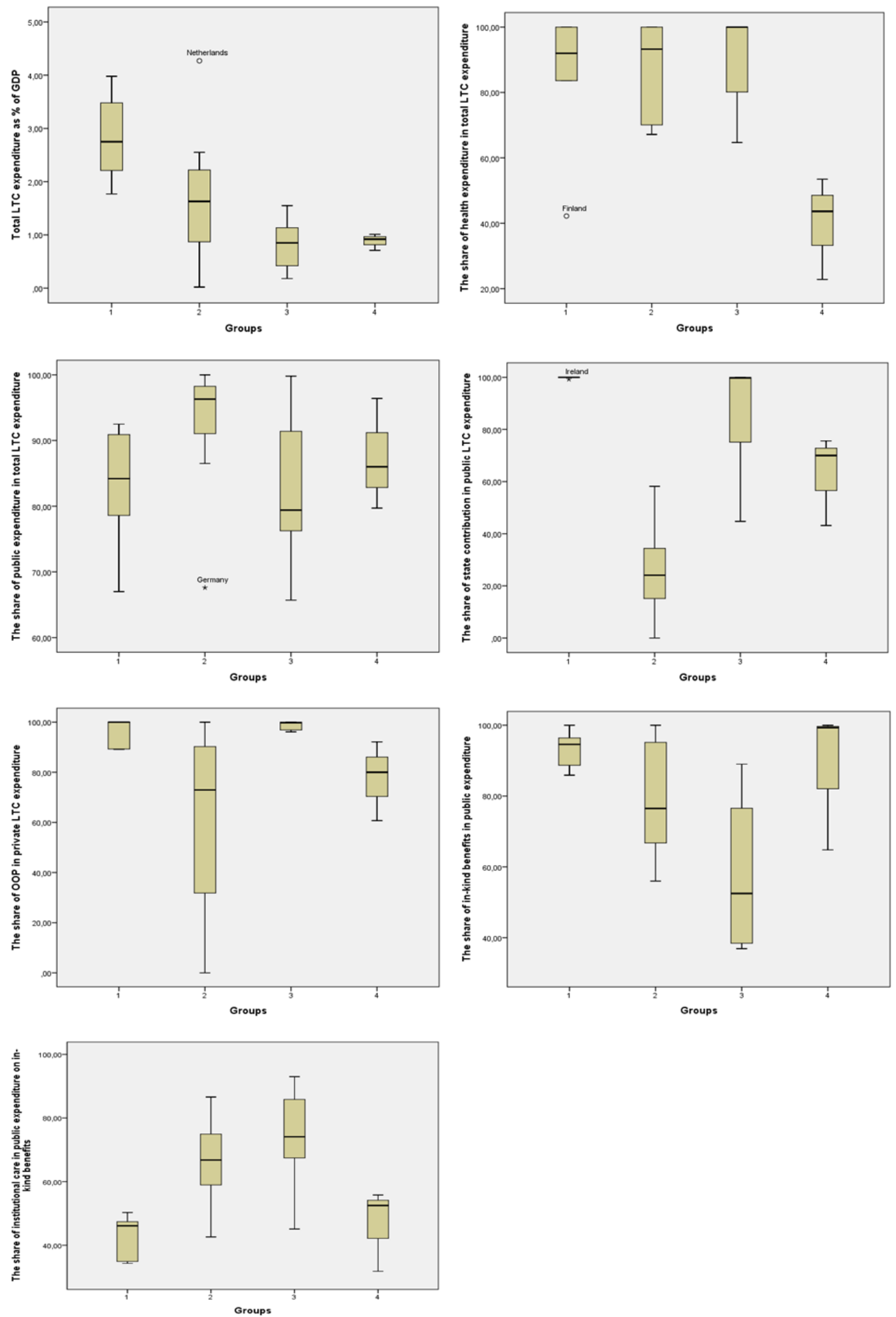

Figure 2. Box-plots of cluster.

Source: Own study.

\section{Discussion}

The aim of this study was to identify relevant indicators related to LTC financing available in international databases and reports, as well as to explore the typologies in LTC financing in the EU/EEA countries based on these indicators. Following the conceptual framework presented at the outset, we discuss differences across the EU/ EEA countries in financial routes/flows from third payers to care receiver and caregiver, as well as from the care receiver to third payer and/or providers via cost-sharing mechanisms. 


\begin{tabular}{|c|c|c|c|c|c|c|c|c|}
\hline Indicators & Group & $N$ & Mean & $\begin{array}{c}\text { Std. } \\
\text { deviation }\end{array}$ & Median & Minimum & Maximum & $\begin{array}{c}\text { ANOVA F } \\
(p)\end{array}$ \\
\hline \multirow{5}{*}{$\begin{array}{l}\text { Total LTC } \\
\text { expenditure } \\
\text { as \% of } \\
\text { GDP (2014, } \\
\text { Eurostat) }\end{array}$} & 1 & 5 & 2.84 & 0.90 & 2.75 & 1.77 & 3.98 & $\begin{array}{c}4.867 \\
(0.012)\end{array}$ \\
\hline & 2 & 7 & 1.73 & 1.41 & 1.63 & 0.02 & 4.27 & \\
\hline & 3 & 7 & 0.81 & 0.51 & 0.85 & 0.18 & 1.55 & \\
\hline & 4 & 3 & 0.88 & 0.15 & .92 & 0.71 & 1.01 & \\
\hline & Total & 22 & 1.57 & 1.21 & 1.31 & 0.02 & 4.27 & \\
\hline \multirow{5}{*}{$\begin{array}{l}\text { The share } \\
\text { of health } \\
\text { expenditure } \\
\text { in total LTC } \\
\text { expenditure } \\
\text { (OECD/Euro- } \\
\text { stat 2014) }\end{array}$} & 1 & 5 & 83.57 & 24.09 & 92.00 & 42.21 & 100.00 & $\begin{array}{c}5.917 \\
(0.005)\end{array}$ \\
\hline & 2 & 7 & 85.80 & 15.82 & 93.25 & 67.18 & 100.00 & \\
\hline & 3 & 7 & 89.29 & 15.67 & 100.00 & 64.71 & 100.00 & \\
\hline & 4 & 3 & 39.99 & 15.65 & 43.66 & 22.83 & 53.47 & \\
\hline & Total & 22 & 80.16 & 23.39 & 92.00 & 22.83 & 100.00 & \\
\hline \multirow{5}{*}{$\begin{array}{l}\text { The share } \\
\text { of public } \\
\text { expenditure } \\
\text { in total LTC } \\
\text { expenditure }\end{array}$} & 1 & 5 & 82.64 & 10.35 & 84.20 & 67.00 & 92.50 & $\begin{array}{c}0.969 \\
(0.429)\end{array}$ \\
\hline & 2 & 7 & 91.79 & 11.54 & 96.30 & 67.60 & 100.00 & \\
\hline & 3 & 7 & 82.89 & 12.08 & 79.40 & 65.70 & 99.80 & \\
\hline & 4 & 3 & 87.37 & 8.43 & 86.00 & 79.70 & 96.40 & \\
\hline & Total & 22 & 86.27 & 11.14 & 86.50 & 65.70 & 100.00 & \\
\hline \multirow{5}{*}{$\begin{array}{l}\text { The share } \\
\text { of state } \\
\text { contribution } \\
\text { in public LTC } \\
\text { expenditure }\end{array}$} & 1 & 5 & 99.85 & 0.34 & 100.00 & 99.24 & 100.00 & $\begin{array}{l}20.394 \\
(0.000)\end{array}$ \\
\hline & 2 & 7 & 25.89 & 19.32 & 24.09 & 0.00 & 58.16 & \\
\hline & 3 & 7 & 84.96 & 22.00 & 99.74 & 44.75 & 100.00 & \\
\hline & 4 & 3 & 62.93 & 17.35 & 70.00 & 43.16 & 75.62 & \\
\hline & Total & 22 & 66.55 & 34.69 & 75.62 & 0.00 & 100.00 & \\
\hline \multirow{5}{*}{$\begin{array}{l}\text { The share of } \\
\text { out-of-pocket } \\
\text { payments in } \\
\text { private LTC } \\
\text { expenditure }\end{array}$} & 1 & 5 & 95.67 & 5.93 & 100.00 & 89.09 & 100.00 & $\begin{array}{c}3.874 \\
(0.027)\end{array}$ \\
\hline & 2 & 7 & 59.59 & 39.29 & 72.97 & 0.00 & 100.00 & \\
\hline & 3 & 7 & 98.51 & 1.80 & 99.71 & 96.12 & 100.00 & \\
\hline & 4 & 3 & 77.61 & 15.84 & 80.00 & 60.71 & 92.12 & \\
\hline & Total & 22 & 82.63 & 27.89 & 96.12 & 0.00 & 100.00 & \\
\hline \multirow{5}{*}{$\begin{array}{l}\text { The share of } \\
\text { in-kind bene- } \\
\text { fits in public } \\
\text { expenditure }\end{array}$} & 1 & 5 & 93.12 & 5.74 & 94.60 & 85.90 & 100.00 & $\begin{array}{c}4.271 \\
(0.019)\end{array}$ \\
\hline & 2 & 7 & 79.47 & 17.58 & 76.50 & 56.00 & 100.00 & \\
\hline & 3 & 7 & 58.34 & 22.46 & 52.50 & 36.90 & 89.00 & \\
\hline & 4 & 3 & 88.03 & 20.12 & 99.30 & 64.80 & 100.00 & \\
\hline & Total & 22 & 77.02 & 21.78 & 84.80 & 36.90 & 100.00 & \\
\hline \multirow{5}{*}{$\begin{array}{l}\text { The share of } \\
\text { institutional } \\
\text { care in public } \\
\text { expenditure } \\
\text { on in-kind } \\
\text { benefits }\end{array}$} & 1 & 5 & 42.60 & 7.46 & 46.10 & 34.30 & 50.30 & $\begin{array}{c}6.255 \\
(0.004) \\
\end{array}$ \\
\hline & 2 & 7 & 66.26 & 14.83 & 66.80 & 42.60 & 86.60 & \\
\hline & 3 & 7 & 74.11 & 16.68 & 74.10 & 45.10 & 93.00 & \\
\hline & 4 & 3 & 46.70 & 13.01 & 52.50 & 31.80 & 55.80 & \\
\hline & Total & 22 & 60.71 & 18.58 & 57.00 & 31.80 & 93.00 & \\
\hline
\end{tabular}

Table IV. Descriptive statistics of the cluster groups.

Source: Own study.

We find that the level of health expenditure varies substantially across the EU/EEA countries. High expenditure is possibly related to higher volumes of formal care like in the Netherlands and the Scandinavian countries [27]. At the same time, the low public expenditure in CEE countries correlates with inadequate provision of LTC services [28].

In all countries reported, LTC expenditure is mostly covered by public resources through different channels.
Some countries finance LTC via taxes (e.g. Scandinavian countries), others via social insurances in the form of compulsory LTC insurance (e.g. Germany) or use a combination of taxation and insurance (e.g. the Netherlands). Also, there are countries, where no discrete financing systems can be distinguished. We can observe that in countries, where LTC is financed by taxes, higher expenditure is observed than in those countries, where LTC is financed by compulsory insurance (e.g. Luxembourg) 
or health insurance resources (e.g. Belgium) [6]. An exception is the Netherlands.

Regarding the benefits, differences are found in the share of expenditure devoted to in-kind benefits and cash benefits, and whether these benefits are universal or means-tested. Differences can be found in the share of costs allocated towards different types of services, e.g. home-based or institutional care. As demonstrated in previous research [29], the LTC financing influences the use of LTC services, which could explain some of the differences and similarities among the countries. It is also important to highlight the increasing role of cash-benefits in the EU Member States due to the decline in the informal care supply. Older EU Member States tend to provide direct benefits to individuals in need of care, whereas new EU member states place more emphasis on benefits for caregivers [30].

Private expenditure in the form of cost-sharing is an essential source of funding in all countries in our sample. We observe a widespread use of co-payments, which is mostly applied for institutional care. These co-payments are income related in most of the countries, but only about one third of the countries also use user's assets to determine the level of cost-sharing. Furthermore, in the present sample, some CEE and Mediterranean countries made the relatives responsible to cover the LTC costs. Nonetheless, this is in line with the family-based model in these countries. While some authors point out that means-testing contributes to the control of utilization of LTC services and decreases moral hazard [31], others argue that means-testing, even though widely used, is related to the creation of more unmet needs and stigma [32]. Nevertheless, countries may apply steep means-testing for institutional care, but they can still offer largely universal benefits like in the Netherlands [33].

Taking into account these diversities in LTC financing, cluster analysis revealed four main typologies in the EU/EEA countries based on the indicators identified in desk research. We observe the highest level of LTC expenditure in the group consisting of Scandinavian countries (Denmark, Sweden, Finland), the UK and Ireland. In these countries, the expenditures are covered mainly by tax revenue, but there is an important role for out-ofpocket payments due to cost-sharing mechanisms. The focus is on in-kind benefits rather than on cash-benefits, with an equal role of home and institutional care. In continental Western-European countries (Belgium, Germany, France, The Netherlands) and in some of the CEE countries (Slovenia, Poland, Slovakia), the level of LTC expenditure varies (from a very high LTC expenditure in the Netherlands to much lower LTC expenditures in Poland and Slovakia). Thus, in a cluster group not all countries have exactly the same characteristics but they do show considerable similarities on some of the characteristics, which allows their grouping in the same cluster. In particular, these countries follow an "insurance model", as expenditure is covered mainly from compulsory contributions. Only in this group, we can observe a role for voluntary insurance. In the group of Southern countries (Spain, Italy) and in some CEE countries (Croatia,
Czech Republic, Latvia, Estonia) as well as in Austria, the average level of LTC financing is lower compared to the previous groups, costs are mainly covered by the state contributions and out-of-pocket payments, with an important role of cash benefits. The fourth group is more diverse and consists only of Hungary, Lithuania and Portugal. These countries have a low expenditure from public resources offering mostly in-kind benefits. Greece forms a case on its own with a very specific LTC financing schemes.

In a previous study [34], a typology of five models to categorize LTC financing schemes is proposed: the public service model (Scandinavian model), the family care model (Mediterranean model), the means-tested model (English model), the insurance based model (continental model) and the Eastern model (post-communist model). These models were formulated based on five dimensions: the role of the state, the mode of financing, the major benefit instrument used, eligibility criteria used and the extent of generosity of benefits granted. This typology is mostly in line with our findings - our Group 1 represents the Scandinavian model and the English model, our Group 2 represents the insurance based (continental) model, Group 3 could be linked to the Mediterranean model. Nevertheless, we find some differences regarding the Eastern model, as we found more diversities in the CEE countries. Some CEE countries, e.g. Slovenia, Poland, Slovakia, are closer to the "insurance-based (continental) model", while the Czech Republic has higher expenditure and a rising focus on cash benefits in comparison to other CEE countries. Furthermore, other CEE countries, like Latvia and Estonia, belong to the group of "Mediterranean model". However, since we focused only on EU/EEA countries, some of the CEE countries were not included in the current study.

As previous studies show [27, 34], the financing of LTC relates to the administrative structures and health care systems or general welfare state models. The results of our cluster analysis also suggest that there is indeed a link between the financial structures of the health care systems and LTC systems. This can be partly explained by the fact that LTC is embedded in the health care system as indicated in our conceptual framework. Our findings demonstrate that those countries that rely on tax-based health care funding as known from e.g. Scandinavian countries, use this form of financing also in LTC. Countries known to finance their health care through the social insurance systems, finance LTC either through compulsory insurance scheme or through health insurance funds.

\section{Data issues}

Previous reports highlighted that there are still some persisting issues in relation to LTC reporting and general data availability $[6,9]$. Our study also confirmed that comprehensive data on LTC financing that would enable a sound comparison across countries is still missing. Furthermore, we found some differences in reporting when different sources were compared. These problems are mostly due to: (1) definitional issues (such as day-care 
being a separate function or being included in inpatient); (2) the division/overlap of tasks between the social and the health care system; and/or (3) general reporting and monitoring issues [7, 8, 34].

For example, reporting on outpatient care and expenditure on social LTC are lacking in several countries. While there are sufficient data reported on the financing of services covered by the health care system, there is only a very limited range of data available on expenditure occurring in the social care systems. Especially in scholarly articles, it is often not certain whether the reported total expenditure on LTC includes both social and health care or only health care expenditure on LTC. For example, OECD [35] reports that Italy spent $0.85 \%$ GDP in total on LTC in 2014, whereas according to other sources [36] public expenditure in Italy amounted to $1.28 \%$ GDP in 2014.

The split and overlap of the social and health care system is considered to be one of the most influential factors that limits the comparability across countries [9]. This issue is especially hampering the analysis of CEE countries due to the fragmented nature of the LTC systems in this region. The absence of good coordination between local and central governments in combination with coordination issues between the social and health care system may be the main reason for this fragmentation [28].

We also found some inconsistencies in the reporting of cash benefits in some of the countries. For example, Belgium and Bulgaria provide cash benefits, but at the same time report that $100 \%$ of their budget is allocated towards in-kind benefits. The reason for this inconsistency can be that cash benefits might be spent on the social system side and are, hence, not demonstrated in Table I. Or in Latvia, as reported, no cash benefits are granted but still we see budget allocation towards cash benefits, which could be related to the different sources used to retrieve information.

Furthermore, the EU reports [6] that the extensive informal care involvement in many countries contributes to underreporting as well. Note that even OECD reports private spending on formal care only. Also, according to the EU report, some countries only collect data, which they feel are necessary for the system to operate. Differences in reporting reflect not only the developmental level of monitoring and reporting, but also the social and cultural differences in the LTC systems, such as the role of families in LTC [37].

There is an urgent need for improved data reporting and availability in relation to LTC financing as it would improve effectiveness and efficiency of countries with better planning for sustainable LTC systems [38]. Without comprehensive data, informed decision making is rather impossible as the problems in LTC systems are blurry and confusing.

\section{Limitations}

One of the main limitations of the study is the availability and reliability of comprehensive statistical data, which hampers the comparison across countries. Due to missing values, some of the countries (mostly the smaller EU/
EEA countries) could not be classified. Yet, the value of our study also lays in identifying and indicating the gaps in the data on LTC financing which need to be addressed. It should be also recognized that the interpretation of the results of the cluster analysis is somewhat subjective and lacks representativeness since several countries were not included due to the lack of data. Nevertheless, we carried out sensitivity checks, applying other methods for the agglomeration of observations (such as between neighbors method), but group memberships seemed robust for most countries.

We only analyzed how LTC resources are collected and spent. The exact financial mechanisms in LTC were not studied due to limited availability of data on this issue, even though, it is an essential part of LTC financing. Also, social protection schemes, such as old age or disability pension schemes, which would give an additional insight in LTC, were beyond the scope of the present study. Moreover, we applied an aggregated approach and did not study within-country differences, in particular the differences in LTC financing in England and Scotland. Future cross-country studies on TLC affiancing need to take these shortcomings into account.

Although we acknowledge the various limitations of our analysis, we believe that by combining desk research with cluster analysis, our study provides insights on the typologies in LTC financing and indicates important directions for future studies in this area.

\section{Conclusions}

The study provided an overview of how LTC resources are collected and spent across EU/EEA countries. We found that LTC financing is rather divers among the EU/EEA countries regarding the total LTC expenditure, and its distribution between the health care and social care system, financial sources as well as the role of in-kind and cash benefits. We identified four main groups of LTC financial mechanisms based on indicators available in international databases and reports. We also underlined some limitations and contradictions related to the indicators of LTC financing, and highlighted the need for comprehensive data, which enables further cross-country comparisons and informed policy discussions on LTC financing.

Since we found that the overlap between the health and social care system might be one of the main reasons for the unavailability of comprehensive data, this issue should be explored more in-depth both in single countries and across countries in further research. Furthermore, literature on the reimbursement mechanisms of LTC services is scarce and research in this area is urgently needed to better understand financial flows between payers and providers.

Generally, there is a need for better quality indicators in the LTC system and specifically, for the social sector. Thus, the EU should promote and facilitate better reporting and monitoring practices in the member states. Improved coordination and cooperation between the social and health care systems as well as between formal and informal care are needed. This would enable a more profound investigation of LTC systems for more sustainable LTC systems in times of demographic changes. 


\section{References}

1. Colombo F., Llena-Nozal A., Mercier J., Tjadens F., OECD health policy studies help wanted? Providing and paying for long-term care: providing and paying for long-term care, OECD Publishing, Paris 2011.

2. EU, Eurostat, 2017, https://ec.europa.eu/eurostat/data/database (accessed: 10.01.2018).

3. Costa-Font J., Courbage C., Zweifel P., Policy dilemmas in financing long-term care in Europe, "Global Policy" 2017; 8: $38-45$.

4. Swartz K., Searching for a balance of responsibilities: OECD countries' changing elderly assistance policies, “Annual Review of Public Health" 2013; 34.

5. Costa-Font J., Courbage C., Financing long-term care in Europe: Institutions, markets and models, Palgrave Macmillan, London 2011.

6. EU, Joint Report on Health Care and Long-Term Care Systems \& Fiscal Sustainability, Vol. 1/2, Brussels 2016, https://ec.europa.eu/info/publications/economy-finance/ joint-report-health-care-and-long-term-care-systems-fiscalsustainability-0_en (accessed: 10.10.2019).

7. EU, The 2015 Ageing Report. Economic and budgetary projection for the 28 EU Member States (2013-2060), Brussels EU 2015.

8. EU, The 2018 Ageing Report: Economic and budgetary projections for the EU Member States (2016-2070), Brussels EU 2018

9. OECD/EU, Health at a Glance - Europe 2016 State of Health in the EU Cycle, Paris 2016, http://www.oecd.org/ health/health-at-a-glance-europe-23056088.htm (accessed: 10.01.2017).

10. Colombo F., Mercier J., Help Wanted? Fair and Sustainable Financing of Long-term Care Services, "Applied Economic Perspectives and Policy" 2012; 34 (2): 316-332. doi:10.1093/aepp/pps005.

11. Allen K., Bednárik R., Campbell L., Dierterich A., Hirch Durrett E., Emilsson T., Glasby J., Gobet P., Kagialari F., Klavus, J., Kümpers S., Leichsenring K., Ljunggren G., Mastroyiannaki T., Meriläinen S., Naiditch M., Nies H., Repetti M., Repkova K., Rodrigues R., Stiehr K., van der Veen R., Wagner L., Weigl B., Governance and finance of long-term care across Europe, Birmingham/Vienna 2011, http://www.birmingham.ac.uk/Documents/college-socialsciences/social-policy/HSMC/research/interlinks-wp6-final. pdf (accessed: 10.09.2019).

12. Mot E., Faber R., Geerts J., Willemé P., Performance of long-term care systems in Europe (117), Brussels 2012, http://www.ancien-longtermcare.eu/sites/default/files/ ENEPRI RR117_ANCIEN_Evaluation Final Report.pdf (accessed: 10.09.2019).

13. Larizgoitia I., Approaches to evaluating LTC systems, in: J. Brodsky, J. Habib, M.J. Hirschfeld (eds.), Key Policy Issues in Long-term Care, WHO, Geneva 2003.

14. Knapp M., Somani A., Long term care, organization and financing, in: G. Carrin, K. Buse, K. Heggenhougen, S.R. Quah (eds.), Health Systems Policy, Finance, and Organization, Academic Press, Oxford 2009.

15. OECD, Accounting and Mapping of Long-term Care Expenditure Under SHA 2011, 2012, http://www.oecd.org/els/
health-systems/AccountingMappingofLTC.pdf (accessed: 10.09.2019).

16. Reinhardt U.E., Economic Relationships in Health Care Health Care Systems in Transition: The Search for Efficiency, OECD Publishing, Paris 1990: 204.

17. Kraus M., Riedel M., Mot E., Willemé P., Röhtling G., Czypionka T., A Typology of Long-term Care Systems in Europe (91), 2010, http://www.ancien-longtermcare.eu/ sites/default/files/ENEPRIRRNo91TypologyofLTCSystemsinEurope.pdf (accessed: 10.01.2018).

18. Bloom D.E., Chatterji S., Kowal P., Lloyd-Sherlock P., McKee M., Rechel B., Rosenberg L., Smith J.P., Macroeconomic implications of population ageing and selected policy responses, "The Lancet” 2015; 385 (9968): 649-657. doi:10.1016/s0140-6736(14)61464-1.

19. Kautto V.T. a. M., Sustaining the Nordic welfare model in the face of population ageing, in: K.H. Sarah Harper, J. Hoffman, K. Howse, G. Leeson (eds.), International Handbook on Ageing and Public Policy, Edward Elgar, Cheltenham, UK 2014: 528.

20. Verbeek-Oudijk D., Woittiez I., Eggink E., Putman L., Who cares in Europe? A comparison of long-term care for the over50s in sixteen European countries, The Hague 2014, http:// www.scp.nl/english/Publications/Publications_by_year/Publi cations_2014/Who_cares_in_Europe (accessed: 10.01.2018).

21. Heger D.K., Thorben K., Care choices in Europe: To each according to his needs? "Ruhr Economic Papers" 2016; 649. doi:10.4419/86788755.

22. CIHI, Health System Performance Frameworks: Aligning Frameworks for Sectors and Organizations to Health Systems, 2015, https://secure.cihi.ca/free_products/Aligning_Frameworks_for_Sectors_and_Organizations_to_Health_Systems. pdf (accessed: 28.01.2018).

23. Wittenberg R., Sandhu B., Knapp M., Funding long-term care: The public and private options, in: E. Mossialos, A. Dixon, J. Figueras, J. Kutzin (eds.), Funding Health Care: Options for Europe, Open University Press, BuckinghamPhiladelphia 2002.

24. Rothgang H., Engelke K., Long-term care: How to organise affordable, sustainable long-term care given the constraints of collective versus individual arrangements and responsibilities, The Netherlands 2009, ec.europa.eu/social/BlobSer vlet?docId=8465\&langId=en (accessed: 02.01.2018).

25. MISSOC, Comparative Tables Database: XII. Longterm care, July 2016, http://www.missoc.org/MISSOC/ INFORMATIONBASE/COMPARATIVETABLES/MISSO CDATABASE/comparativeTableSearch.jsp (accessed: 28.01.2018).

26. Courtin E., Jemiai N., Mossialos E., Mapping support policies for informal carers across the European Union, "Health Policy" 2014; 118 (1): 84-94. doi:10.1016/j.healthpol.2014.07.013.

27. EU, Adequate social protection for long-term care needs in an ageing society, European Union, Luxembourg 2014.

28. Hirose K., Czepulis-Rutkowska Z.A., Challenges in Longterm Care of the Elderly in Central and Eastern Europe, Geneva 2016, http://www.ilo.org/wcmsp5/groups/public/--europe/---ro-geneva/---sro-budapest/documents/publication/wcms_532427.pdf (accessed: 10.10.2019). 
29. Bakx P., Financial Incentives in Long-Term Care (Institute of Health Policy and Management (iBMG) Doctoral Thesis), Erasmus University Rotterdam, Rotterdam 2015.

30. Riedel M., Kraus M., Differences and similarities in monetary benefits for informal care in old and new EU member states, "International Journal of Social Welfare" 2016; 25 (1): 7-17. doi:10.1111/ijsw.12157.

31. Costa-Font J., Zigante V., Long Term Care Coverage in Europe: A Case for 'Implicit Insurance Partnerships', London 2014, http://www.lse.ac.uk/LSEHealthAndSocialCare/pdf/ LSEHealthworkingpaperseries/LSEHWP37.pdf (accessed: 03.09.2019).

32. Rodrigues R., Long-term care - the problem of sustainable financing, Luxembourg 2015, https://goo.gl/wN8kwS (accessed: 10.12.2019).

33. Muir T., Measuring social protection for long-term care (1815-2015), Paris 2017, http://dx.doi.org/10.1787/ a411500a-en (accessed: 10.01.2019).

34. Companje K.P., Financing high medical risks, A.U. Press (ed.), Amsterdam University Press, Amsterdam 2014.

35. OECD, Health expenditure and financing: Health expenditure indicators, 2017, http://dx.doi.org/10.1787/data00349-en (accessed: 10.01.2018) from OECD Health Statistics.

36. Greve B., Long-term care for the elderly in Europe - developments and prospects, Routledge, London-New York 2017.

37. Vučkovič L.A., Bednaš M., Caprirolo G., Čelebič T., Dodič J., Fajić L., Ferk B., Glažar M., Hafner M., Hribernik M., Ivas K., Jurančič S., Kajzer A., Zupančič R.K., Koprivnikar Šušteršič M., Kovač M., Kušar J., Masten A., Markič J., Mervic H., Murn A., Nenadič T., Pečar J., Perko M., Rojec M., Sodja U., Stare M., Šuc D., Tavčar B., Tršelič Selan A., Trošt M., Vidrih A., Zakotnik I., Zver E., Development Report Slovenia 2014, Ljubljana 2014, http://www.umar.gov. si/fileadmin/user_upload/publikacije/pr/2014/Apor_2014. pdf (accessed: 25.01.2018).

38. Scheil-Adlung X., Long-term care protection for older persons: A review of coverage deficits in 46 countries, Vol. ESS, Working Paper, International Labour Organization, Geneva 2015: 1-115.

39. Bodiroga-Vukobrat N., Croatia - Pension, health and longterm care. ASISP country document, Gesellschaft für Versicherungswissenschaften und -gestaltung e.V., Cologne 2014.

40. Kroneman M., B. W., van den Berg M., Groenewegen P., de Jong J., van Ginneken E., Netherlands - Health System Review, in: R. Busse (Series ed.), Health Systems in Transition, Vol. 18, WHO \& European Observatory on Health Systems and Policies, Copenhagen 2016: 1-239.

41. Bäcker G., Reform of the long-term care insurance in Germany, 2016, ec.europa.eu/social/BlobServlet?docId=16074 \&langId=en (accessed: 10.01.2018).

42. Jessoula M., Pavolini E., Italy - Pension, health and longterm care. ASISP country document, Gesellschaft für Versicherungswissenschaften und -gestaltung e.V., Cologne 2014.

43. Cordina G., Borg A., Malta - Pension, health and longterm care. ASISP country document. Gesellschaft für Ver- sicherungswissenschaften und -gestaltung e.V., Cologne 2014.

44. Vidlund M., Preusker U., Finland - Pension, health and long-term care. ASISP country document, Gesellschaft für Versicherungswissenschaften und -gestaltung e.V., Cologne 2014.

45. Spruit G., Luxembourg - Pension, health and long-term care. ASISP country document, Gesellschaft für Versicherungswissenschaften und -gestaltung e.V., Cologne 2014.

46. De Pietro C., C. P., Sturny I., Crivelli L., Edwards-Garavoglia S., Spranger A., W. F. Q. W., Switzerland - Health System Review, in: R. Busse (Series ed.), Health Systems in Transition, Vol. 17, WHO \& European Observatory on Health Systems and Policie, Copenhagen 2015: 1-288.

47. Segaert S., Belgium - Pensions, health and long-term care. ASISP country document, Gesellschaft für Versicherungswissenschaften und -gestaltung e.V., Cologne 2014.

48. Burke S., Considine M., Ireland - Pension, health and longterm care. ASISP country document, Gesellschaft für Versicherungswissenschaften und -gestaltung e.V., Cologne 2014.

49. Zaglmayer B., Liechtenstein - Pension, health and longterm care. ASISP country document, Gesellschaft für Versicherungswissenschaften und -gestaltung e.V., Cologne 2014.

50. Cylus J., R. E., Findley L., Longley M., O’Neill C., Steel D., United Kingdom - Health System Review, in: E.N.E. v. Ginneken (Series ed.), Health Systems in Transition, Vol. 17, WHO \& European Observatory on Health Systems and Policies, Copenhagen 2015: 1-125.

51. Fink M., Austria - Pensions, health and long-term care. ASISP country document, Gesellschaft für Versicherungswissenschaften und -gestaltung e.V., Cologne 2014: 1-52.

52. Võrk A., Paat-Ahi G., Estonia - Pension, health and longterm care. ASISP country document, Gesellschaft für Versicherungswissenschaften und -gestaltung e.V., Cologne 2014.

53. Vagac L., Golias P., Zachar D., Slovakia - Pension, health and long-term care. ASISP country document, Gesellschaft für Versicherungswissenschaften und -gestaltung e.V., Cologne 2014.

54. Medaiskis T., Jankauskienè D., Lithuania - Pension, health and long-term care. ASISP country document, Gesellschaft für Versicherungswissenschaften und -gestaltung e.V., Cologne 2014.

55. Sigurgeirsdóttir S., Waagfjörð J., Maresso A., Iceland Health system review, in: S. Thomson, E. v. Ginneken (Series eds.), Health Systems in Transition, Vol. 16, WHO, Copenhague 2014: 1-211.

56. Ringard Å., Sagan A., Saunes I.S., Lindahl A.K., Norway - Health system review. Health Systems in Transition, Vol. 15: Health Systems in Transition, WHO, Copenhague 2013: $1-162$.

57. Tinios P., Greece: forced transformation in a deep crisis, in: B. Greve (ed.), Long-term Care for the Elderly in Europe: Development and Prospects, Routledge, London-New York 2017.

58. Zilvere R., Latvia - Pension, health and long-term care. ASISP country document, Gesellschaft für Versicherungswissenschaften und -gestaltung e.V., Cologne 2014. 